\title{
THE IMPACT OF THE MARIEL BOATLIFT ON THE MIAMI LABOR MARKET
}

\author{
DAVID CARD*
}

\begin{abstract}
Using data from the Current Population Survey, this paper describes the effect of the Mariel Boatlift of 1980 on the Miami labor market. The Mariel immigrants increased the Miami labor force by $7 \%$, and the percentage increase in labor supply to less-skilled occupations and industries was even greater because most of the immigrants were relatively unskilled. Nevertheless, the Mariel influx appears to have had virtually no effect on the wages or unemployment rates of less-skilled workers, even among Cubans who had immigrated earlier. The author suggests that the ability of Miami's labor market to rapidly absorb the Mariel immigrants was largely owing to its adjustment to other large waves of immigrants in the two decades before the Mariel Boatlift.
\end{abstract}

$\mathrm{O}$ NE of the chief concerns of immigration policy-makers is the extent to which immigrants depress the labor market opportunities of less-skilled natives. Despite the presumption that an influx of immigrants will substantially reduce native wages, existing empirical studies suggest that the effect is small. (See the survey by Greenwood and McDowell [1986] and studies by Grossman [1982], Borjas [1987], and Lalonde and Topel [1987].) There are two leading explanations for this finding. First, immigrants have, on average, only slightly lower skills than the native population. Thus, econometric studies based on the distribution of the existing stock of immigrants probably understate the effect of unskilled immigration on less-skilled

* The author is Professor of Economics, Princeton University. He thanks George Borjas, Alan Krueger, Bruce Meyer, and seminar participants at Princeton University for their comments.

A data appendix with copies of the computer programs used to generate the tables in this paper is available from the author at the Industrial Relations Section, Firestone Library, Princeton University, Princeton, NJ 08544. natives. Second, the locational choices of immigrants and natives presumably depend on expected labor market opportunities. Immigrants tend to move to cities where the growth in demand for labor can accommodate their supply. Even if new immigrants cluster in only a few cities (as they do in the United States), inter-city migration of natives will tend to offset the adverse effects of immigration.

These considerations illustrate the difficulty of using the correlation across cities between wages and immigrant densities to measure the effect of immigration on the labor market opportunities of natives. They also underscore the value of a natural experiment that corresponds more closely to an exogenous increase in the supply of immigrants to a particular labor market.

The experiences of the Miami labor market in the aftermath of the Mariel Boatlift form one such experiment. From May to September 1980 , some 125,000 Cuban immigrants arrived in Miami on a flotilla of privately chartered boats. Their arrival was the consequence of an unlikely sequence of events culminating in Castro's 
declaration on April 20, 1980, that Cubans wishing to emigrate to the United States were free to leave from the port of Mariel. ${ }^{1}$ Fifty percent of the Mariel immigrants settled permanently in Miami. The result was a $7 \%$ increase in the labor force of Miami and a 20\% increase in the number of Cuban workers in Miami.

This paper summarizes the effects of the Boatlift on the Miami labor market, focusing on wages and unemployment rates of less-skilled workers. The analysis is based on individual micro-data for 1979-85 from the merged outgoing rotation group samples of the Current Population Survey (CPS).

Three features of the Mariel incident and the Census data greatly facilitate the analysis. First, the CPS sample of the Miami metropolitan area is relatively large: roughly 1,200 individuals per month. Second, a comprehensive picture of the Miami labor market in the months just before the Mariel Boatlift is available from the 1980 Census, which was conducted on April 1, 1980. Finally, unlike most other ethnic groups, Cubans are separately identified in the CPS questionnaire. Thus, it is possible to estimate wage rates, unemployment rates, and other economic indicators for both Cubans and nonCubans in the Miami labor market, and to measure the effects of the Mariel immigration on the two groups separately.

\section{Overview of the Miami Labor Market Before the Boatlift}

For at least a decade prior to the Mariel Boatlift, Miami was the most immigrantintensive city in the country. Tabulations from the 1980 Census indicate that $35.5 \%$ of residents in the Miami Standard Metropolitan Statistical Area (SMSA) were foreign-born, ${ }^{2}$ compared to $22.3 \%$ in Los

\footnotetext{
${ }^{1}$ See Masud-Piloto (1988, chaps. 6-7) for an overview of the political developments that led to the Mariel Boatlift.

${ }^{2}$ See U.S. Department of Commerce (1983). The Miami SMSA consists of Dade County, and includes Miami City as well as a number of smaller towns and cities. Throughout this paper, I use "Miami" to refer to this broader geographic region.
}

Angeles, the city with the next-highest immigrant fraction, and $6.1 \%$ nationwide. At the time of the Census, $56 \%$ of immigrants in Miami were of Cuban origin. The remaining foreign-born residents, who accounted for $16 \%$ of the Miami population, included other Hispanic groups and a broad selection of Caribbean and European nationals.

Miami also has a significant black population. The fraction of black residents was $15.0 \%$ in 1970 and had increased to $17.3 \%$ by the time of the 1980 Census. The large concentrations of both immigrants and blacks makes Miami ideal for studying the effect of increased immigration on the labor market opportunities of black natives.

Table 1 describes the four major groups in the Miami labor force in 1979: white non-Hispanics; black non-Hispanics; $\mathrm{Cu}-$ bans (foreign-born and native-born); and other Hispanics. For simplicity, I have restricted attention to individuals age 16-61, a group that represents roughly $60 \%$ of the Miami population. The fractions of Cubans and blacks in the 16-61 age group are $27.2 \%$ and $26.3 \%$, respectively, and the fractions of white nonHispanics and non-Cuban Hispanics are $34.4 \%$ and $11.1 \%$. Overall, $73 \%$ of $16-$ 61-year-olds participated in the labor force, with somewhat higher rates among whites and Cubans and lower rates among blacks and other Hispanics. Education levels in Miami are somewhat below the national average: the mean of completed education for 16-61-year-olds in 1979 was 11.8 years in Miami, compared with 12.2 years nationwide.

The occupation distributions in rows 7-17 of Table 1 give a crude indication of the degree of labor market competition among the four groups. Cubans and other Hispanics have very similar occupation distributions, with a higher representation in craft and operative occupations than either whites or blacks. Blacks are more highly concentrated in laborer and servicerelated occupations, and are significantly under-represented in managerial occupations.

A useful summary measure of the 
Table 1. Characteristics of 16-61-Year-Olds in Miami, 1979.

\begin{tabular}{|c|c|c|c|c|c|}
\hline Characteristic & Whites & Blacks & Cubans & Hispanics & $A l l$ \\
\hline \multicolumn{6}{|l|}{ Characteristics of Population Age 16-61 } \\
\hline 1. Estimated Number (1000's) & 319.3 & 244.1 & 252.4 & 102.9 & 928.4 \\
\hline 2. Mean Education & 12.8 & 11.4 & 11.0 & 11.6 & 11.8 \\
\hline 3. Percent in Labor Force & 75.6 & 68.3 & 77.2 & 68.8 & 73.1 \\
\hline \multicolumn{6}{|l|}{ Characteristics of Those in Labor Force } \\
\hline 4. Estimated Number (1000's) & 241.3 & 166.6 & 194.7 & 70.8 & 678.2 \\
\hline 5. Mean Education & 13.1 & 11.8 & 11.3 & 11.9 & 12.1 \\
\hline 6. Percent Age 16-24 & 21.1 & 24.1 & 22.0 & 26.0 & 22.8 \\
\hline \multicolumn{6}{|c|}{ Occupation Distribution (Percent of Employed) } \\
\hline 7. Professional and Technical & 19.1 & 10.9 & 9.5 & 10.1 & 13.2 \\
\hline 8. Managers & 15.7 & 2.8 & 8.6 & 8.1 & 9.4 \\
\hline 9. Sales & 6.2 & 4.4 & 7.8 & 7.6 & 6.5 \\
\hline 10. Clerical & 21.9 & 21.0 & 19.1 & 20.9 & 20.9 \\
\hline 11. Craftsmen & 13.3 & 9.4 & 15.1 & 12.7 & 12.8 \\
\hline 12. Operatives & 4.4 & 8.4 & 19.4 & 16.7 & 11.1 \\
\hline 13. Transportation Operatives & 2.6 & 8.1 & 5.4 & 5.9 & 5.2 \\
\hline 14. Laborers & 5.1 & 10.5 & 4.7 & 4.0 & 6.3 \\
\hline 15. Farm Workers & 1.1 & 0.1 & 0.4 & 0.8 & 0.6 \\
\hline 16. Less-Skilled Service Workers & 5.0 & 13.3 & 6.1 & 10.2 & 8.0 \\
\hline 17. More-Skilled Service Workers & 5.7 & 10.9 & 4.0 & 3.0 & 6.2 \\
\hline
\end{tabular}

Notes: White and black groups exclude hispanics. Hispanic group includes all hispanics other than Cubans. Less-skilled service workers include cleaning and food service workers. More-skilled service workers include health service, personal service, and protective service workers.

Source: Based on samples of employed workers in the outgoing rotation groups of the Current. Population Survey in 1979.

overlap in the occupation distributions of the different groups is the average percent increase in labor supply in occupations held by one group that would result from a one percentage point increase in the overall fraction of workers in a second group. ${ }^{3}$ This index has the simple form $\Sigma_{j} s_{1 j} s_{2 j} / s_{j}$, where $s_{1 j}$ is the fraction of workers of group 1 in occupation $j, s_{2 j}$ is the fraction of workers of group 2 in occupation $j$, and $s_{j}$ is the fraction of all workers in occupation $j$. Based on the distributions in Table 1, an inflow of immigrants resulting in a one percentage point increase in the fraction of Cubans in Miami would lead to a weighted average increase of $.95 \%$ in the supply of labor to occupations held by whites. Under the same conditions the increase would be $.99 \%$ for blacks, $1.02 \%$ for non-Cuban Hispanics, and $1.06 \%$ for Cubans themselves. These calculations suggest that the overlap between the occupational distributions of the four groups is relatively high.

\footnotetext{
${ }^{3}$ This index is derived in Altonji and Card (1989:15-16).
}

\section{The Mariel Immigration}

Due to the unauthorized nature of the Boatlift, no exact count of the number of Mariel immigrants is available, and there is little precise information on the characteristics or final destinations of the irnmigrants. This section summarizes some of the available information, including data from the March 1985 Mobility Supplement to the Current Population Survey, which allows Mariel immigrants to be distinguished from other Cubans.

Most sources estimate the number of Mariel immigrants at between 120,000 and 125,000. A recent Census Bureau report (U.S. Department of Commerce 1988:9) states that 126,000 refugees entered the United States as "Cuban Entrants" (the special immigration status awarded to the Mariel refugees) between April 1980 and June 1981. Based on the settlement pattern of earlier Cubans, it is widely assumed that about one-half of these refugees settled permanently in Miami. The Census Bureau "Experimental County Population Estimates" file 
shows an increase of 80,500 in the Dade County population between April 1 and July 1 of $1980 ; 59,800$ of these new entrants were age 16-61. My own tabulations from the CPS indicate that the Cuban share of the 16-61 age group increased from $27 \%$ in 1979 to $33 \%$ in $1981 .{ }^{4} \mathrm{~A}$ similar increase is registered in CPS-based estimates of the Cuban share of the 16-61-year-old labor force, which changed from $37.2 \%$ in 1979 to $44.8 \%$ in 1981. Assuming that the Cuban share of the labor force would have remained constant between 1979 and 1981 in the absence of the Boatlift, these figures suggest that the Mariel immigration added approximately 45,000 to the Miami labor force-an increase of $7 \%$.

From the first days of the Boatlift, the characteristics of the Mariel immigrants (hereafter referred to as Mariels) have been a subject of controversy. Among those who were permitted to leave Cuba were several hundred inmates of mental hospitals and jails. Many of these individuals were arrested by immigration officials upon their arrival in the United States, and over 1,000 were sent to a special prison facility in Atlanta to await deportation back to Cuba. ${ }^{5}$ A similar number were arrested for crimes committed in the United States, and they still await determination of their ultimate immigration status. ${ }^{6}$ Contemporary reports indicate that the Mariels included a relatively high fraction of less-skilled workers and a high fraction of individuals with low English ability (Business Week 1980).

Although the regular Current Population Survey questionnaire does not distinguish Mariels from other foreign and

\footnotetext{
${ }^{4}$ These tabulations are presented in greater detail in an earlier version of this paper (Card 1989, Table 2).

${ }^{5}$ See Masud-Piloto (1988:100-103). Under a 1984 agreement a total of 2,700 Mariel immigrants were to be returned to Cuba.

${ }^{6}$ Mariel immigrants were blamed for, and indeed seem to have committed, many crimes in the first few months after the Boatlift. Wilbanks (1984) reported that 38 of the 574 homicides in Miami in 1980 were committed by Mariel immigrants. Disaffected Mariels were involved in 6 airline highjacking attempts in August 1980. See Masud-Piloto (1988:95-96).
}

native-born Cubans, the March 1985 Mobility Supplement survey asked each respondent where he or she lived in March 1980 (one month before the start of the Boatlift). Table 2 presents a descriptive summary of the Cuban population interviewed in this survey, classified by whether the respondent claimed to be living abroad or in the United States five years earlier. The sample sizes, particularly of post- 1980 entrants, are small. ${ }^{7}$ Nevertheless, these data confirm the general impression that Mariels, on average, have less education, are somewhat younger, and are more likely to be male than other Cubans. The figures in Table 2 also suggest that the Mariels have lower labor force attachment and lower occupational attainment than other Cubans. Mariels are more heavily concentrated in laborer and service occupations, and are less likely to hold sales, clerical, and craft jobs.

The unadjusted wage gap between Mariels and other Cubans is 34\%. Part of this differential is clearly attributable to the lower education levels and younger ages of the Mariels. A simple linear regression for the logarithm of average hourly earnings fitted to the sample of Cubans with earnings in 1984 suggests that the Mariels earned $18 \%$ lower wages than other Cubans, controlling for education, potential experience, and gender (the standard error of this estimate is .08). This gap presumably reflects the combination of lower language ability and a shorter assimilation time in the United States among the Mariels, as well as any differences in ability or motivation between the earlier and later Cuban immigrants.

\section{The Effect of the \\ Mariel Immigration on the Miami Labor Market}

Observers in Miami at the time of the Boatlift noted the strain caused by the Mariel immigration. The homicide rate

\footnotetext{
${ }^{7}$ The weighted count of all Cubans in the March 1985 CPS who entered the United States after 1980 is 85,800 , which is only $69 \%$ of the estimated 125,000 Mariel refugees.
} 
Table 2. Characteristics of Mariel Immigrants and Other Cubans: Tabulations from March 1985 CPS.

\begin{tabular}{lcc}
\hline & Mariel & All other \\
Characteristic & Immigrants & Cubans \\
\hline Educational Attainment & & \\
(Percent of Population in Each & & \\
Category): & & \\
No High School & 56.5 & 25.4 \\
Some High School & 9.1 & 13.3 \\
Completed High School & 9.5 & 33.4 \\
Some College & 6.8 & 12.0 \\
Completed College & 18.1 & 15.8 \\
Percent Male & 55.6 & 50.7 \\
Percent Under 30 in 1980 & 38.7 & 29.6 \\
Mean Age in 1980 (Years) & 34.9 & 38.0 \\
Percent in Miami in 1985 & 53.9 & 52.4 \\
Percent Worked in 1984 & 60.6 & 73.4 \\
Mean Log Hourly Earnings & 1.37 & 1.71 \\
Occupation Distribution (Percent & & \\
Employed in Each Category): & & \\
$\quad$ Professional/Managers & 19.3 & 21.0 \\
Technical & 0.0 & 1.5 \\
Sales & 4.5 & 11.2 \\
Clerical & 2.5 & 13.5 \\
Craftsmen & 9.5 & 19.9 \\
Operatives & 19.1 & 13.8 \\
Transportation Ops. & 3.8 & 4.3 \\
Laborers & 10.8 & 3.3 \\
Farm Workers & 0.0 & 1.8 \\
Less-Skilled Service & 26.0 & 7.4 \\
$\quad$ More-Skilled Service & 4.6 & 2.3 \\
Sample Size & 50 & 528 \\
Weighted Count & 42,300 & 476,900 \\
\hline & & \\
\hline
\end{tabular}

Note: The sample consists of all Cubans in the March 1985 Current Population Survey age 21-66 (i.e., age $16-61$ in 1980). Mariel immigrants are identified as those Cubans who stated that they lived outside the United States 5 years previously.

increased nearly $50 \%$ between 1979 and 1980 (see Wilbanks 1984:142). On the weekend of May 17, 1980, a three-day riot occurred in several black neighborhoods, killing 13. A government-sponsored committee that was set up to investigate the riot identified other long-standing grievances in the black community as its cause, but cited the labor market competition of Cuban refugees as an important background factor (Governor of Florida 1980: 14-15).

Another widely cited indicator of the labor market pressure created by the Mariel influx is the Miami unemployment rate, which rose from $5.0 \%$ in April 1980 to $7.1 \%$ in July. Over the same period state and national unemployment rates followed a similar pattern, suggesting that the changes in Miami were not solely a response to the Mariel influx. Nevertheless, widespread joblessness of refugees throughout the summer of 1980 contributed to a perception that labor market opportunities for less-skilled natives were threatened by the Mariel immigrants. ${ }^{8}$

Tables 3 and 4 present simple averages of wage rates and unemployment rates for whites, blacks, Cubans, and other Hispanics in the Miami labor market between 1979 and 1985. For comparative purposes, I have assembled similar data for whites, blacks, and Hispanics in four other cities: Atlanta, Los Angeles, Houston, and Tampa-St. Petersburg. These four cities were selected both because they had relatively large populations of blacks and Hispanics and because they exhibited a pattern of economic growth similar to that in Miami over the late 1970 s and early 1980s. A comparison of employment growth rates (based on establishment-level data) suggests that economic conditions were very similar in Miami and the average of the four comparison cities between 1976 and 1984 .

The wage data in Table 3 reveal several features of the Miami labor market. Perhaps most obvious is that earnings are lower in Miami than in the comparison cities. The differentials in 1979 ranged from $8 \%$ for whites to $15 \%$ for blacks. More surprising is that real earnings levels of whites in both Miami and the comparison cities were fairly constant between 1979 and 1985. This pattern contrasts with the general decline in real wages in the U.S. economy over this period (see Bound and Johnson 1989:5-6) and underscores the relatively close correspondence between economic conditions in Miami and the comparison cities.

\footnotetext{
${ }^{8}$ For example, a Florida State Employment Service official and a Department of Labor Wage and Hours Division official noted downward pressure on wages and working conditions in the unskilled segment of the Miami labor market (Business Week 1980).
} 
Table 3. Logarithms of Real Hourly Earnings of Workers Age 16-61 in Miami and Four Comparison Cities, 1979-85.

\begin{tabular}{|c|c|c|c|c|c|c|c|}
\hline Group & 1979 & 1980 & 1981 & 1982 & 1983 & 1984 & 1985 \\
\hline \multicolumn{8}{|l|}{ Miami: } \\
\hline Whites & $\begin{array}{l}1.85 \\
(.03)\end{array}$ & $\begin{array}{l}1.83 \\
(.03)\end{array}$ & $\begin{array}{l}1.85 \\
(.03)\end{array}$ & $\begin{array}{l}1.82 \\
(.03)\end{array}$ & $\begin{array}{l}1.82 \\
(.03)\end{array}$ & $\begin{array}{l}1.82 \\
(.03)\end{array}$ & $\begin{array}{c}1.82 \\
(.05)\end{array}$ \\
\hline Blacks & $\begin{array}{l}1.59 \\
(.03)\end{array}$ & $\begin{array}{c}1.55 \\
(.02)\end{array}$ & $\begin{array}{l}1.61 \\
(.03)\end{array}$ & $\begin{array}{l}1.48 \\
(.03)\end{array}$ & $\begin{array}{l}1.48 \\
(.03)\end{array}$ & $\begin{array}{l}1.57 \\
(.03)\end{array}$ & $\begin{array}{c}1.60 \\
(.04)\end{array}$ \\
\hline Cubans & $\begin{array}{l}1.58 \\
(.02)\end{array}$ & $\begin{array}{l}1.54 \\
(.02)\end{array}$ & $\begin{array}{l}1.51 \\
(.02)\end{array}$ & $\begin{array}{l}1.49 \\
(.02)\end{array}$ & $\begin{array}{l}1.49 \\
(.02)\end{array}$ & $\begin{array}{l}1.53 \\
(.03)\end{array}$ & $\begin{array}{l}1.49 \\
(.04)\end{array}$ \\
\hline Hispanics & $\begin{array}{l}1.52 \\
(.04)\end{array}$ & $\begin{array}{l}1.54 \\
(.04)\end{array}$ & $\begin{array}{l}1.54 \\
(.05)\end{array}$ & $\begin{array}{l}1.53 \\
(.05)\end{array}$ & $\begin{array}{l}1.48 \\
(.04)\end{array}$ & $\begin{array}{l}1.59 \\
(.04)\end{array}$ & $\begin{array}{c}1.54 \\
(.06)\end{array}$ \\
\hline \multicolumn{8}{|c|}{ Comparison Cities: } \\
\hline Whites & $\begin{array}{c}1.93 \\
(.01)\end{array}$ & $\begin{array}{c}1.90 \\
(.01)\end{array}$ & $\begin{array}{l}1.91 \\
(.01)\end{array}$ & $\begin{array}{l}1.91 \\
(.01)\end{array}$ & $\begin{array}{l}1.90 \\
(.01)\end{array}$ & $\begin{array}{c}1.91 \\
(.01)\end{array}$ & $\begin{array}{c}1.92 \\
(.01)\end{array}$ \\
\hline Blacks & $\begin{array}{l}1.74 \\
(.01)\end{array}$ & $\begin{array}{l}1.70 \\
(.02)\end{array}$ & $\begin{array}{l}1.72 \\
(.02)\end{array}$ & $\begin{array}{l}1.71 \\
(.01)\end{array}$ & $\begin{array}{l}1.69 \\
(.02)\end{array}$ & $\begin{array}{l}1.67 \\
(.02)\end{array}$ & $\begin{array}{l}1.65 \\
(.03)\end{array}$ \\
\hline Hispanics & $\begin{array}{c}1.65 \\
(.01)\end{array}$ & $\begin{array}{l}1.63 \\
(.01)\end{array}$ & $\begin{array}{l}1.61 \\
(.01)\end{array}$ & $\begin{array}{c}1.61 \\
(.01)\end{array}$ & $\begin{array}{c}1.58 \\
(.01)\end{array}$ & $\begin{array}{l}1.60 \\
(.01)\end{array}$ & $\begin{array}{c}1.58 \\
(.02)\end{array}$ \\
\hline
\end{tabular}

Note: Entries represent means of log hourly earnings (deflated by the Consumer Price Index $-1980=100$ ) for workers age 16-61 in Miami and four comparison cities: Atlanta, Houston, Los Angeles, and 'Tampa-St. Petersburg. See note to Table 1 for definitions of groups.

Source: Based on samples of employed workers in the outgoing rotation groups of the Current Population Survey in 1979-85. Due to a change in SMSA coding procedures in 1985, the 1985 sample is based on individuals in outgoing rotation groups for January-June of 1985 only.

In contrast to the pattern for whites, the trends in earnings for nonwhites and Hispanics differ somewhat between Miami and the comparison cities. Black wages in Miami were roughly constant from 1979 to 1981 , fell in 1982 and 1983 , and rose to their previous level in 1984. Black earnings in the comparison cities, on the other hand, show a steady downward trend between 1979 and 1985 . These data provide no evidence of a negative impact of the Mariel immigration on black wages in Miami. The data do suggest a relative downturn in black wages in Miami during 1982-83. It seems likely, however, that this downturn reflects an unusually severe cyclical effect associated with the 1982-83 recession. (I return to this issue in Table 6 , below.)

Wage rates for non-Cuban Hispanics in Miami were fairly stable between 1979 and 1985, with only a slight dip in 1983. In contrast, Hispanic wage rates in the comparison cities fell about 6 percentage points over this period. Again, there is no evidence of a negative effect in Miami, either in the immediate post-Mariel period or over the longer run.

Table 3 does indicate a decline in Cuban wage rates relative to the wage rates of other groups in Miami. Relative to the wages of whites, for example, Cuban wages fell by $6-7$ percentage points between 1979 and 1981. Assuming that the wages of earlier Cuban immigrants were constant, this decline is consistent with the addition of 45,000 Mariel warkers to the pool of Cubans in the Miami labor force, and with the $34 \%$ wage differential between Mariels and other Cubans noted in Table 3. A more thorough analysis of Cuban wages is presented in Table 7 , below.

The unemployment rates in Table 4 lead to the same general conclusions as the wage data in Table 3. There is no evidence that the Mariel influx adversely affected the unemployment rate of either whites or blacks. The unemployment rates suggest a severe cyclical downturn in the black labor market in Miami in 1982-83. Black unemployment rates in Miami, which had been 
Table 4. Unemployment Rates of Individuals Age 16-61 in Miami and Four Comparison Cities, 1979-85.

(Standard Errors in Parentheses)

\begin{tabular}{lccccccc}
\hline Group & 1979 & 1980 & 1981 & 1982 & 1983 & 1984 & 1985 \\
\hline Miami: & & & & & & & \\
Whites & 5.1 & 2.5 & 3.9 & 5.2 & 6.7 & 3.6 & 4.9 \\
& $(1.1)$ & $(0.8)$ & $(0.9)$ & $(1.1)$ & $(1.1)$ & $(0.9)$ & $(1.4)$ \\
Blacks & 8.3 & 5.6 & 9.6 & 16.0 & 18.4 & 14.2 & 7.8 \\
& $(1.7)$ & $(1.3)$ & $(1.8)$ & $(2.3)$ & $(2.5)$ & $(2.3)$ & $(2.3)$ \\
Cubans & 5.3 & 7.2 & 10.1 & 10.8 & 13.1 & 7.7 & 5.5 \\
& $(1.2)$ & $(1.3)$ & $(1.5)$ & $(1.5)$ & $(1.6)$ & $(1.4)$ & $(1.7)$ \\
Hispanics & 6.5 & 7.7 & 11.8 & 9.1 & 7.5 & 12.1 & 3.7 \\
& $(2.3)$ & $(2.2)$ & $(3.0)$ & $(2.5)$ & $(2.1)$ & $(2.4)$ & $(1.9)$ \\
Comparison & & & & & & & \\
Whites & 4.4 & 4.4 & 4.3 & 6.8 & 6.9 & 5.4 & 4.9 \\
& $(0.3)$ & $(0.3)$ & $(0.3)$ & $(0.3)$ & $(0.3)$ & $(0.3)$ & $(0.4)$ \\
Blacks & 10.3 & 12.6 & 12.6 & 12.7 & 18.4 & 12.1 & 13.3 \\
& $(0.8)$ & $(0.9)$ & $(0.9)$ & $(0.9)$ & $(1.1)$ & $(0.9)$ & $(1.3)$ \\
Hispanics & 6.3 & 8.7 & 8.3 & 12.1 & 11.8 & 9.8 & 9.3 \\
& $(0.6)$ & $(0.6)$ & $(0.6)$ & $(0.7)$ & $(0.7)$ & $(0.6)$ & $(0.8)$ \\
\hline
\end{tabular}

Note: Entries represent means of unemployment indicator variable for individuals age 16-61 in Miami and four comparison cities: Atlanta, Houston, Los Angeles, and Tampa-St. Petersburg. Samples are based on individuals in the labor force. See notes to Table 3 for definitions of groups and data sources.

2-4 points lower than those in the comparison cities from 1979 to 1981 , equalled or exceeded those in the comparison cities from 1982 to 1984 . The 1985 data indicate a return to the pre-1982 pattern, although the sampling errors are large enough to prevent precise inferences.

Unlike the situation for whites and blacks, there was a sizable increase in Cuban unemployment rates in Miami following the Mariel immigration. Cuban unemployment rates were roughly 3 percentage points higher during 1980-81 than would have been expected on the basis of earlier (and later) patterns. Assuming that the unemployment rates of earlier Cuban immigrants were unaffected by the Mariel influx, this effect is consistent with unemployment rates of around $20 \%$ among the Mariels themselves. Although far from conclusive, this simple calculation suggests that the increase in Cuban unemployment rates could easily be explained as a result of the addition of the Mariel refugees to the Cuban population, with little or no effect on earlier immigrants.

The simple averages of wages and unemployment rates in Tables 3 and 4 , which combine workers of all ages and education levels, do not directly address the question of whether the Mariel immigration reduced the earnings of lessskilled natives in Miami. A more direct answer is provided by the data in Table 5 . In order to identify "less-skilled" workers, I fit a linear regression equation for the logarithm of hourly earnings to workers in the comparison cities. The explanatory variables in this regression included education, potential experience, squared potential experience, indicator variables for each gender and race group, and interactions of the gender-race indicators with potential experience and squared potential experience. I then used the estimated coefficients from this equation to form a predicted wage for each non-Cuban worker in Miami, and sorted the sample from each year into quartiles on the basis of predicted wage rates.

This procedure provides a simple way to identify more- and less-skilled workers in the Miami labor market. Means of actual log wages for each quartile and year are presented in the first four columns of 
Table 5. Means of Log Wages of Non-Cubans in Miami by Quartile

of Predicted Wages, 1979-85.

(Standard Errors in Parentheses)

\begin{tabular}{|c|c|c|c|c|c|}
\hline \multirow[b]{2}{*}{ Year } & \multicolumn{4}{|c|}{ Mean of Log Wage by Quartile of Predicted Wage } & \multirow{2}{*}{$\begin{array}{c}\text { Difference of } \\
\text { Means: } 4 \text { th }-1 \text { st }\end{array}$} \\
\hline & 1st Quart. & 2nd Quart. & 3rd Quart. & 4th Quart. & \\
\hline 1979 & $\begin{array}{l}1.31 \\
(.03)\end{array}$ & $\begin{array}{l}1.61 \\
(.03)\end{array}$ & $\begin{array}{l}1.71 \\
(.03)\end{array}$ & $\begin{array}{l}2.15 \\
(.04)\end{array}$ & $\begin{array}{l}.84 \\
(.05)\end{array}$ \\
\hline 1980 & $\begin{array}{l}1.31 \\
(.03)\end{array}$ & $\begin{array}{l}1.52 \\
(.03)\end{array}$ & $\begin{array}{l}1.74 \\
(.03)\end{array}$ & $\begin{array}{l}2.09 \\
(.04)\end{array}$ & $\begin{array}{l}.77 \\
(.05)\end{array}$ \\
\hline 1981 & $\begin{array}{l}1.40 \\
(.03)\end{array}$ & $\begin{array}{l}1.57 \\
(.03)\end{array}$ & $\begin{array}{l}1.79 \\
(.03)\end{array}$ & $\begin{array}{l}2.06 \\
(.04)\end{array}$ & $\begin{array}{c}.66 \\
(.05)\end{array}$ \\
\hline 1982 & $\begin{array}{l}1.24 \\
(.03)\end{array}$ & $\begin{array}{l}1.57 \\
(.03)\end{array}$ & $\begin{array}{l}1.77 \\
(.03)\end{array}$ & $\begin{array}{c}2.04 \\
(.04)\end{array}$ & $\begin{array}{l}.80 \\
(.05)\end{array}$ \\
\hline 1983 & $\begin{array}{l}1.27 \\
(.03)\end{array}$ & $\begin{array}{l}1.53 \\
(.04)\end{array}$ & $\begin{array}{l}1.76 \\
(.03)\end{array}$ & $\begin{array}{l}2.11 \\
(.05)\end{array}$ & $\begin{array}{l}.84 \\
(.06)\end{array}$ \\
\hline 1984 & $\begin{array}{l}1.33 \\
(.03)\end{array}$ & $\begin{array}{l}1.59 \\
(.04)\end{array}$ & $\begin{array}{l}1.80 \\
(.04)\end{array}$ & $\begin{array}{l}2.12 \\
(.04)\end{array}$ & $\begin{array}{l}.79 \\
(.05)\end{array}$ \\
\hline 1985 & $\begin{array}{l}1.27 \\
(.04)\end{array}$ & $\begin{array}{l}1.57 \\
(.04)\end{array}$ & $\begin{array}{l}1.81 \\
(.04)\end{array}$ & $\begin{array}{l}2.14 \\
(.05)\end{array}$ & $\begin{array}{l}.87 \\
(.06)\end{array}$ \\
\hline
\end{tabular}

Note: Predicted wage is based on a linear prediction equation for the log wage fitted to individuals in four comparison cities; see text. The sample consists of non-Cubans (male and female, white, black, and Hispanic) between the ages of 16 and 61 with valid wage data in the earnings supplement of the Current Population Survey. Wages are deflated by the Consumer Price Index $(1980=100)$.

Table 5 . The difference in mean wages between the first and fourth quartiles, which provides an index of the spread in the wage distribution, is presented in the fifth column of the table.

If the Mariel immigration reduced the wages of less-skilled natives, one would expect to observe a decline in the wage of workers in the lowest skill quartile, at least relative to workers in the upper quartile. The actual averages show no evidence of this effect. Apart from the temporary increase in relative wages of workers in the lowest quartile between 1979 and 1981, the distribution of non-Cubans' wages in the Miami labor market was remarkably stable between 1979 and 1985. Taken together with the data in Table 3 , these data provide little evidence of a negative effect of the Mariel influx on the earnings of natives.

A final check is provided in Table 6, which contains more detailed information on wages, employment rates, and unemployment rates for blacks in Miami between 1979 and 1985. I separately analyzed the set of all blacks and the set of blacks with less than 12 years of education in order to isolate any stronger effect on the less-skilled segment of the black population. For both groups I calculated the differential in wages between Miami and the comparison cities (both the unadjusted difference in mean log ways and a regression-adjusted differential that controls for education, gender, marital status, part-time status, private/public employment, and potential experience) and the differentials in the employment-population rate and the unemployment rate between Miami and the comparison cities.

As indicated in Table 3, the wage differential for blacks in Miami relative to those in the comparison cities decreased slightly between 1979 and 1981. The differential increased substantially in 1982, but then began a steady downward trend after 1983 . By 1985 , the wage gap was less than $5 \%$ for all black workers, and was actually positive for less-educated blacks. The magnitudes of the regressionadjusted wage differentials are not significantly different from the unadjusted wage differentials, and show no evidence of any effect of the Mariel immigration on black wages.

A similar conclusion emerges from the pattern of differentials in employment- 
Table 6. Comparison of Wages, Unemployment Rates, and Employment Rates for Blacks in Miami and Comparison Cities.

(Standard Errors in Parentheses)

\begin{tabular}{|c|c|c|c|c|c|c|c|c|}
\hline \multirow[b]{4}{*}{ Year } & \multicolumn{4}{|c|}{ All Backs } & \multicolumn{4}{|c|}{ Low-Education Blacks } \\
\hline & \multirow{2}{*}{\multicolumn{2}{|c|}{$\begin{array}{c}\text { Difference in } \\
\text { Log Wages, } \\
\text { Miami - Comparison }\end{array}$}} & \multicolumn{2}{|c|}{$\begin{array}{c}\text { Difference in } \\
\text { Emp./Unemp., } \\
\text { Miami - Comparison }\end{array}$} & \multirow{2}{*}{\multicolumn{2}{|c|}{$\begin{array}{c}\text { Difference in } \\
\text { Log Wages, } \\
\text { Miami - Comparison } \\
\end{array}$}} & \multicolumn{2}{|c|}{$\begin{array}{c}\text { Difference in } \\
\text { Emp./Unemp., } \\
\text { Miami - Comparison }\end{array}$} \\
\hline & & & Emp. - & & & & $E m p .-$ & \\
\hline & Actual & Adjusted & Pop. Rate & Unemp. Rate & Actual & Adjusted & Pop. Rate & Unemp. Rate \\
\hline 1979 & $\begin{array}{r}-.15 \\
(.03)\end{array}$ & $\begin{array}{r}-.12 \\
(.03)\end{array}$ & $\begin{array}{c}.00 \\
(.03)\end{array}$ & $\begin{array}{r}-2.0 \\
(1.9)\end{array}$ & $\begin{array}{r}-.13 \\
(.05)\end{array}$ & $\begin{array}{r}-.15 \\
(.05)\end{array}$ & $\begin{array}{c}.03 \\
(.04)\end{array}$ & $\begin{array}{l}-.8 \\
(3.8)\end{array}$ \\
\hline 1980 & $\begin{array}{c}-.16 \\
(.03)\end{array}$ & $\begin{array}{c}-.12 \\
(.03)\end{array}$ & $\begin{array}{c}.05 \\
(.03)\end{array}$ & $\begin{array}{c}-7.1 \\
(1.6)\end{array}$ & $\begin{array}{r}-.07 \\
(.05)\end{array}$ & $\begin{array}{c}-.07 \\
(.05)\end{array}$ & $\begin{array}{c}.03 \\
(.04)\end{array}$ & $\begin{array}{r}-8.2 \\
(3.5)\end{array}$ \\
\hline 1981 & $\begin{array}{r}-.11 \\
(.03)\end{array}$ & $\begin{array}{c}-.10 \\
(.03)\end{array}$ & $\begin{array}{c}.02 \\
(.03)\end{array}$ & $\begin{array}{c}-3.0 \\
(2.0)\end{array}$ & $\begin{array}{r}-.05 \\
(.05)\end{array}$ & $\begin{array}{c}-.11 \\
(.05)\end{array}$ & $\begin{array}{c}.04 \\
(.04)\end{array}$ & $\begin{array}{r}-7.7 \\
(4.2)\end{array}$ \\
\hline 1982 & $\begin{array}{c}-.24 \\
(.03)\end{array}$ & $\begin{array}{r}-.20 \\
(.03)\end{array}$ & $\begin{array}{r}-.06 \\
(.03)\end{array}$ & $\begin{array}{c}3.3 \\
(2.4)\end{array}$ & $\begin{array}{r}-.17 \\
(.05)\end{array}$ & $\begin{array}{r}-.20 \\
(.05)\end{array}$ & $\begin{array}{r}-.04 \\
(.04)\end{array}$ & $\begin{array}{c}.6 \\
(4.7)\end{array}$ \\
\hline 1983 & $\begin{array}{c}-.21 \\
(.03)\end{array}$ & $\begin{array}{c}-.15 \\
(.03)\end{array}$ & $\begin{array}{c}-.02 \\
(.03)\end{array}$ & $\begin{array}{c}.1 \\
(2.7)\end{array}$ & $\begin{array}{c}-.13 \\
(.06)\end{array}$ & $\begin{array}{c}-.11 \\
(.05)\end{array}$ & $\begin{array}{c}.04 \\
(.04)\end{array}$ & $\begin{array}{c}-3.3 \\
(4.7)\end{array}$ \\
\hline 1984 & $\begin{array}{r}-.10 \\
(.03)\end{array}$ & $\begin{array}{c}-.05 \\
(.03)\end{array}$ & $\begin{array}{c}-.04 \\
(.03)\end{array}$ & $\begin{array}{c}2.1 \\
(2.4)\end{array}$ & $\begin{array}{c}-.04 \\
(.06)\end{array}$ & $\begin{array}{r}-.03 \\
(.05)\end{array}$ & $\begin{array}{c}.05 \\
(.04)\end{array}$ & $\begin{array}{c}.1 \\
(4.7)\end{array}$ \\
\hline 1985 & $\begin{array}{r}-.05 \\
(.04)\end{array}$ & $\begin{array}{c}-.01 \\
(.04)\end{array}$ & $\begin{array}{r}-.06 \\
(.04)\end{array}$ & $\begin{array}{r}-5.5 \\
(2.6)\end{array}$ & $\begin{array}{l}.18 \\
(.07)\end{array}$ & $\begin{array}{c}.09 \\
(.07)\end{array}$ & $\begin{array}{c}.00 \\
(.06)\end{array}$ & $\begin{array}{r}-4.7 \\
(5.6)\end{array}$ \\
\hline
\end{tabular}

Notes: Low-education blacks are those with less than 12 years of completed education. Adjusted differences in log wages between blacks in Miami and comparison cities are obtained from a linear regression model that includes education, potential experience, and other control variables; see text. Wages are deflated by the Consumer Price Index $(1980=100)$. "Emp.-Pop. Rate" refers to the employment:population ratio. "Unemp. Rate" refers to the unemployment rate among those in the labor force.

population ratios and unemployment rates. ${ }^{9}$ Among all blacks, there is some evidence of a relative decline in the employmentto-population ratio in Miami between 1979 and 1985.10 This effect seems to have started in 1982, and is less pronounced among low-education blacks than among those with more education. As noted in Ta-

\footnotetext{
${ }^{9}$ I also computed regression-adjusted employmentpopulation and unemployment gaps using simple linear probability models. The explanatory power of the statistical models is so low, however, that the adjusted differentials are almost identical to the unadjusted differentials.

${ }_{10}$ Although they are not reported in Table 6, I have also constructed differentials in the labor force participation rate between Miami and the comparison cities. For blacks as a whole these show a decline in relative participation rates in Miami starting in 1982 , although the decline is only temporary for the low-education group. The differential in labor force participation rates is approximately equal to the differential in the employment-population rate plus the differential in the unemployment rate multiplied by the average labor force participation rate $(.7$ for the overall group, .55 for the low-education group).
}

ble 4 , the series of unemployment rate differentials indicates a sharp downturn in labor market opportunities for blacks in 1982. Given the lag between the arrival of the Mariels and the emergence of this unemployment gap, however, the gap seems more likely to have resulted from the 1982 recession than from the influx of lessskilled immigrants.

The effects of the Mariel immigration on Cuban labor market outcomes are examined in detail in Table 7 . The first column of the table reproduces the means of $\log$ wages in each year from the third row of Table 3 . The second column gives predicted log wages of Cubans in Miami, using estimated coefficients from a regression equation fit to Hispanics in the four comparison cities. The gap between actual and predicted wages is presented in the third column of the table. These series show that the 9 percentage point decline in Cuban real wage rates in Miami between 1979 and 1985 was a result of two 
Table 7. Means of Log Wages of Cubans in Miami: Actual and Predicted, and by Quartile of Predicted Wages.

(Standard Errors in Parentheses)

\begin{tabular}{|c|c|c|c|c|c|c|c|c|c|c|}
\hline \multirow[b]{3}{*}{ Year } & \multicolumn{3}{|c|}{$\begin{array}{c}\text { Mean of Log Wages } \\
\text { Log in Miami }\end{array}$} & \multirow{2}{*}{\multicolumn{4}{|c|}{$\begin{array}{c}\text { Mean of Log } \\
\text { Wages by Quartile } \\
\text { of Predicted Wages }\end{array}$}} & \multirow{3}{*}{$\begin{array}{c}\text { Mean Log Wage } \\
\text { of Cubans } \\
\text { Outside Miami }\end{array}$} & \multirow{2}{*}{\multicolumn{2}{|c|}{$\begin{array}{c}\text { Difference in } \\
\text { Cuban Wages, } \\
\text { Miami - Rest-of-U.S. }\end{array}$}} \\
\hline & & & Actual- & & & & & & & \\
\hline & Actual & dicted & dicted & $1 s t$ & $2 n d$ & $3 r d$ & $4 t h$ & & Actual & justed. \\
\hline 1979 & $\begin{array}{l}1.58 \\
(.02)\end{array}$ & $\begin{array}{l}1.73 \\
(.02)\end{array}$ & $\begin{array}{r}-.15 \\
(.03)\end{array}$ & $\begin{array}{l}1.31 \\
(.02)\end{array}$ & $\begin{array}{l}1.44 \\
(.03)\end{array}$ & $\begin{array}{l}1.64 \\
(.04)\end{array}$ & $\begin{array}{l}1.90 \\
(.05)\end{array}$ & $\begin{array}{l}1.71 \\
(.04)\end{array}$ & $\begin{array}{r}-.13 \\
(.04)\end{array}$ & $\begin{array}{r}-.10 \\
(.04)\end{array}$ \\
\hline 1980 & $\begin{array}{c}1.54 \\
(.02)\end{array}$ & $\begin{array}{l}1.68 \\
(.02)\end{array}$ & $\begin{array}{r}-.14 \\
(.03)\end{array}$ & $\begin{array}{l}1.25 \\
(.02)\end{array}$ & $\begin{array}{l}1.49 \\
(.05)\end{array}$ & $\begin{array}{l}1.59 \\
(.04)\end{array}$ & $\begin{array}{l}1.81 \\
(.05)\end{array}$ & $\begin{array}{l}1.66 \\
(.03)\end{array}$ & $\begin{array}{r}-.12 \\
(.04)\end{array}$ & $\begin{array}{r}-.06 \\
(.03)\end{array}$ \\
\hline 1981 & $\begin{array}{l}1.51 \\
(.02)\end{array}$ & $\begin{array}{l}1.68 \\
(.02)\end{array}$ & $\begin{array}{r}-.17 \\
(.03)\end{array}$ & $\begin{array}{l}1.23 \\
(.03)\end{array}$ & $\begin{array}{l}1.43 \\
(.03)\end{array}$ & $\begin{array}{l}1.55 \\
(.04)\end{array}$ & $\begin{array}{l}1.80 \\
(.05)\end{array}$ & $\begin{array}{l}1.63 \\
(.03)\end{array}$ & $\begin{array}{r}-.13 \\
(.04)\end{array}$ & $\begin{array}{r}-.09 \\
(.03)\end{array}$ \\
\hline 1982 & $\begin{array}{l}1.49 \\
(.02)\end{array}$ & $\begin{array}{l}1.68 \\
(.02)\end{array}$ & $\begin{array}{r}-.19 \\
(.03)\end{array}$ & $\begin{array}{l}1.27 \\
(.03)\end{array}$ & $\begin{array}{l}1.43 \\
(.04)\end{array}$ & $\begin{array}{l}1.50 \\
(.04)\end{array}$ & $\begin{array}{l}1.77 \\
(.06)\end{array}$ & $\begin{array}{l}1.71 \\
(.03)\end{array}$ & $\begin{array}{r}-.22 \\
(.04)\end{array}$ & $\begin{array}{r}-.12 \\
(.03)\end{array}$ \\
\hline 1983 & $\begin{array}{l}1.48 \\
(.03)\end{array}$ & $\begin{array}{l}1.65 \\
(.02)\end{array}$ & $\begin{array}{r}-.17 \\
(.03)\end{array}$ & $\begin{array}{l}1.16 \\
(.02)\end{array}$ & $\begin{array}{l}1.41 \\
(.04)\end{array}$ & $\begin{array}{l}1.56 \\
(.04)\end{array}$ & $\begin{array}{c}1.80 \\
(.06)\end{array}$ & $\begin{array}{l}1.62 \\
(.03)\end{array}$ & $\begin{array}{r}-.14 \\
(.04)\end{array}$ & $\begin{array}{r}-.08 \\
(.03)\end{array}$ \\
\hline 1984 & $\begin{array}{l}1.53 \\
(.03)\end{array}$ & $\begin{array}{l}1.69 \\
(.02)\end{array}$ & $\begin{array}{r}-.17 \\
(.03)\end{array}$ & $\begin{array}{l}1.20 \\
(.03)\end{array}$ & $\begin{array}{l}1.40 \\
(.04)\end{array}$ & $\begin{array}{l}1.65 \\
(.05)\end{array}$ & $\begin{array}{c}1.88 \\
(.06)\end{array}$ & $\begin{array}{l}1.63 \\
(.03)\end{array}$ & $\begin{array}{r}-.10 \\
(.04)\end{array}$ & $\begin{array}{r}-.08 \\
(.03)\end{array}$ \\
\hline 1985 & $\begin{array}{l}1.49 \\
(.04)\end{array}$ & $\begin{array}{l}1.67 \\
(.03)\end{array}$ & $\begin{array}{r}-.18 \\
(.05)\end{array}$ & $\begin{array}{l}1.19 \\
(.06)\end{array}$ & $\begin{array}{l}1.43 \\
(.06)\end{array}$ & $\begin{array}{l}1.53 \\
(.08)\end{array}$ & $\begin{array}{l}1.80 \\
(.09)\end{array}$ & $\begin{array}{l}1.77 \\
(.06)\end{array}$ & $\begin{array}{r}-.27 \\
(.07)\end{array}$ & $\begin{array}{r}-.19 \\
(.05)\end{array}$ \\
\hline
\end{tabular}

Notes: Predicted wage is based on a linear prediction equation for the log wage fitted to individuals in four comparison cities; see text. Predicted wages for Cubans in Miami are based on coefficients for Hispanics in comparison cities. The adjusted wage gap between Cubans in Miami and Cubans in the rest of the U.S. are obtained from a linear regression model that includes education, potential experience, and other control variables; see text. Wages are deflated by the Consumer Price Index $(1980=100)$.

complementary factors: a $6 \%$ relative decline in the "quality" of the Cuban labor force in Miami, as measured by the decline in their predicted wages, and a 3 percentage point increase in the quality-adjusted wage gap between Cuban workers in Miami and Hispanic workers in the comparison cities. Two-thirds of the wage decline is therefore attributed to the changing productivity characteristics of the Cuban labor force, and one-third to a decrease in the return to skills for Cubans in the Miami labor market.

The next four columns of Table 7 give the means of log wages for Cuban workers in each quartile of the distribution of predicted wages (using the same prediction equation as was used to form the means in column 2). These means suggest that real wage rates of Cubans in the lowest quartile of the wage distribution declined by 11-12 percentage points between 1979 and 1985. The decline is smaller for workers in the higher quartiles, but there is some variation between
1984 and 1985, and in light of the sampling errors it is difficult to draw precise inferences. The difference between the means of the first and fourth quartiles is 9 percentage points higher in 1984 than 1979, but the gap narrows to only 2 points in 1985 . These figures are consistent with a larger decline in earnings at the low end of the Cuban wage distribution after the Mariel immigration, as might be expected from the addition of a large group of relatively unskilled workers to the pool of Cubans. The extent of the decline, however, is not precisely measured.

An alternative method to assess the effect of the Mariel immigration on the earnings of Cubans in the Miami labor market is to compare Cuban wages in Miami to the wages of Cubans elsewhere in the United States. Since the fraction of Mariels in the Cuban labor force is roughly the same inside and outside Miami, this comparison controls for any unobservable differences in skill between 
the Mariels and other Cubans (due to language ability, for example). ${ }^{11}$ The ninth and tenth columns of Table 7 contain estimates of the wage differential for Cubans in Miami relative to those elsewhere in the country, both unadjusted and adjusted for education, gender, part-time status, private sector/public sector employment, marital status (interacted with gender), and potential experience.

The earnings differentials computed in this way are roughly constant between 1979 and 1984. The 1982 unadjusted wage differential is 10 percentage points larger than earlier or later ones, but the regression-adjusted differential is not significantly different from any of the other differentials. The 1985 data also indicate a slightly higher Cuban wage rate outside Miami. In any case, a comparison of Cuban wages inside and outside the Miami labor market shows no evidence of a widening gap in the years immediately following the Mariel immigration. On the assumption that the Mariel influx had no effect on the wage rates of other Cubans outside Miami, this finding suggests that the observed downturn in Cuban wages in Miami can be attributed solely to the "dilution" of the Cuban labor force with less-skilled Mariel workers.

\section{Interpretation of the Findings}

The data in Table 3-7 point to two conclusions. First, the Mariel immigration had essentially no effect on the wages or employment outcomes of non-Cuban workers in the Miami labor market. Second, and perhaps even more surprising, the Mariel immigration had no strong effect on the wages of other Cubans. The observed decline in average Cuban wage rates in Miami after 1980 is no larger than would be expected by simply adding the Mariel immigrants to the pool of Cuban workers, assuming that the Mariels earned

\footnotetext{
11 This proposition is strictly true only if the unobservable differences have a constant proportional effect on all Mariels, independent of the level of observed skills or location choice.
}

about one-third less than other comparable Cubans (as the March 1985 data suggest). This conclusion is confirmed by a comparison of Cuban wage rates inside and outside Miami, which shows no relative change over the period.

These conclusions lead naturally to the question of how the Miami labor market was able to absorb a $7 \%$ increase in the labor force with no adverse effects. One possible answer is that the Mariels displaced other immigrants and natives who would have moved to Miami in the early 1980s had the Boatlift not occurred. Some evidence on this hypothesis is provided by comparing population growth rates in Miami to those in other Florida cities. From 1970 to 1980 , the Miami population grew at an annual rate of $2.5 \%$ per year while the population of the rest of Florida grew at a rate of $3.9 \%$. After April 1, 1980 , the growth rate in Miami slowed to $1.4 \%$ per year while that in the rest of the state decreased to $3.4 \% .^{12}$ The greater slowdown in Miami suggests that the Boatlift may have actually held back long-run population growth in Miami. In fact, the population of Dade county in 1986 was about equal to the pre-Boatlift projection of the University of Florida Bureau of Economic and Business Research under their "low population growth" scenario (see Florida Statistical Abstract 1981, Table 1.24).

Nevertheless, data from the March 1985 Current Population Survey suggest that Miami continued to attract new foreignborn immigrants after 1980. A total of $2.7 \%$ of all non-Cuban immigrants who arrived in the United States after March 1980 were living in Miami in March 1985. At the time of the 1980 Census, however, only $1.8 \%$ of all non-Cuban immigrants in the United States lived in Miami. Thus, Miami attracted "more than its share" of new non-Cuban immigrants to the country in the five-year period after the Mariel immigration. The implication is that the slowdown in the rate of growth of the

\footnotetext{
12 These figures are obtained from U.S. Department of Commerce (1971, Table 32, and 1988, Table 1).
} 
Miami SMSA after June 1980 occurred because of a change in the net migration rate of natives and older cohorts of immigrants, rather than because of a change in the inflow rate of new immigrants. This finding is consistent with the pattern of domestic migration between 1970 and 1980 identified by Filer (1988), who found a strong negative correlation across SMSAs between the net inmigration rate of natives and the inmigration rate of immigrants.

A second explanation for the rapid absorption of the Mariel immigrants is the growth of industries that utilize relatively unskilled labor. Altonji and Card's (1989) tabulations from the 1970 and 1980 Censuses indicate that a small set of industries employ a large fraction of immigrants, and that these industries expanded more rapidly between 1970 and 1980 in cities with large immigrant populations than in other cities. The immigrantintensive industries identified in their analysis are apparel and textiles, agriculture, furniture, private household services, hotels and motels, eating and drinking establishments, and business services. These are relatively low-wage industries that employ large numbers of semi-skilled operatives and laborers.

A comparison of the industry distributions of employment in Miami and the entire country before and after the Mariel Boatlift shows little change in the relative importance of immigrant-intensive industries in Miami. ${ }^{13}$ Nevertheless, these tabulations suggest that the industry distribution in Miami in the late 1970s was well suited to handle an influx of unskilled immigrants. Textile and apparel industries were particularly prominent in $\mathrm{Mi}$ ami, with $5.5 \%$ of total employment in these industries as compared to only $2.3 \%$ nationwide. Seventy-five percent of workers in textiles and apparel and $45 \%$ of workers in other manufacturing industries

\footnotetext{
${ }^{13}$ These tabulations are reported in Card (1989, Table 9). Pre-Boatlift data are based on the 1979 and 1980 March Current Population Surveys. PostBoatlift data are based on the March 1984 and March 1985 CPS.
}

were Cubans. Although employment in immigrant-intensive industries did not expand after the Boatlift, and the Cuban share of employment in these industries was relatively stable, the Mariels may have simply replaced earlier cohorts of Cuban immigrants as the latter moved to more desirable jobs.

\section{Conclusions}

The experiences of the Miami labor market in the aftermath of the Mariel Boatlift provide a natural experiment with which to evaluate the effect of unskilled immigration on the labor market opportunities of native workers. The Mariel immigrants increased the labor force of the Miami metropolitan area by $7 \%$. Because most of these immigrants were relatively unskilled, the proportional increase in labor supply to less-skilled occupations and industries was much greater.

Yet, this study shows that the influx of Mariel immigrants had virtually no effect on the wage rates of less-skilled nonCuban workers. Similarly, there is no evidence of an increase in unemployment among less-skilled blacks or other nonCuban workers. Rather, the data analysis suggests a remarkably rapid absorption of the Mariel immigrants into the Miami labor force, with negligible effects on other groups. Even among the Cuban population there is no indication that wages or unemployment rates of earlier immigrants were substantially affected by the arrival of the Mariels.

Despite the clear-cut nature of these findings, some caution is required in their interpretation, since the Miami labor market is far from typical of other local labor markets in the United States. Although the arrival of some 60,000 refugees in only a six-month period occasioned problems for the Mariel immigrants, in many respects Miami was better prepared to receive them than any other city. In the two decades before the Mariel Boatlift Miami had absorbed a continuing flow of Cubans, and in the years since the Boatlift it has continued to receive large numbers 
of Nicaraguans and other Central Americans. Thus, the Mariel immigration can be seen as part of a long-run pattern that distinguishes Miami from most other American cities.

Two factors that may have been especially important in facilitating the absorption of the Mariel immigrants are related to the distinctive character of the Miami labor market. First, Miami's industry structure was well suited to make use of an influx of unskilled labor. This structure, and particularly the high concentration of textile and apparel industries, evolved over the previous two decades in response to earlier waves of immigrants, and may have allowed the Mariel immigrants to take up unskilled jobs as earlier Cuban immigrants moved to better ones. Second, because of the high concentration of Hispanics in Miami, the lack of Englishspeaking ability among the Mariels may have had smaller effects than could be expected for other immigrants in other cities.

A final factor in the Mariel immigration is the response of domestic migration. A comparison of Miami growth rates to those in the rest of Florida suggests that the net migration rate of natives and earlier immigrants into the Miami area slowed considerably after the Boatlift. To some extent the Mariels may have displaced other migrants from within the United States who could have been expected to move to Miami.

\section{REFERENCES}

Altonji, Joseph, and David Card. 1989. "The Effects of Immigration on the Labor Market Outcomes of Natives." Princeton University Industrial Relations Section Working Paper Number 256, August.

Borjas, George. 1987. "Immigrants, Minorities, and Labor Market Competition." Industrial and Labor Relations Review, Vol. 40 (April), pp. 382-92.

Bound, John, and George Johnson. 1989. "Changes in the Structure of Wages During the 1980's: An Evaluation of Alternative Explanations." National Bureau of Economic Research Working Paper Number 2983, May.

Business Week. 1980. "The New Wave of Cubans Is Swamping Miami." No. 2651 (August 25), pp. 86-88.

Card, David. 1989. "The Impact of the Mariel Boatlift on the Miami Labor Market." National Bureau of Economic Research Working Paper Number 3069, August.

Filer, Randall. 1988. "The Impact of Immigrant Arrivals on Migratory Patterns of U.S. Workers." Unpublished manuscript, Hunter College and the Graduate Center, City University of New York, October.

Governor of Florida. 1980. Report of the Governor's Dade County Citizen's Committee. Miami.

Greenwood, Michael, and John McDowell. 1984. "The Factor Market Consequences of U.S. Immigration." Journal of Economic Literature, Vol. 34 (December), pp. 1738-72.

Grossman, Jean. 1982. "The Substitutability of Natives and Immigrants in Production." Review of
Economics and Statistics, Vol. 64 (November), pp. 596-603.

Lalonde, Robert, and Robert Topel. 1987. "Labor Market Adjustments to Increased Immigration." Unpublished manuscript, University of Chicago Graduate School of Business, September.

Masud-Piloto, Felix Roberto. 1988. With Open Arms: Cuban Migration to the United States. Totowa, N.J.: Rowman \& Littlefield.

United States Department of Commerce, Bureau of the Census. 1971. 1970 Census of PopulationNumber of Inhabitants: United States Summary (PC1A1). Washington, D.C.: GPO.

1983. 1980 Census of Population-Characteristics of the Population: Detailed Population Characteristics. Vol. 1, Chap. D, Part 2, Florida: PC80-1-D11. Washington, D.C.: GPO.

1988. Current Population Reports-Population Estimates and Projections: United States Population Estimates by Age, Sex, and Race: 1980 to 1987. Series P-25, No. 1022. Washington, D.C.: GPO, March. 1988. Current Population Reports-Local Population Estimates: South 1986 Population and 1985 Per Capita Income Estimates for Counties and Incorporated Places. Series P-26, No. 86-S-SC. Washington, D.C.: GPO, March

University of Florida Bureau of Economics and Business Research. 1981. Florida Statistical Abstract. Gainesville: University Presses of Florida.

Wilbanks, William. 1984. Murder in Miami: An Analysis of Homicide Patterns and Trends in Dade County, Florida, 1917-1983. Lanham, Md.: University Press of America. 